\title{
Peter F. Sugar, 1919-1999
}

Peter F. Sugar was one of the leading specialists of his generation in the fields of central European, Balkan, and Ottoman history. Born in Budapest, he studied at the Lutheran Gymnasium, played on the Hungarian National Ice Hockey Team, and served in the Hungarian cavalry. Sent by his parents to Istanbul just before Hungary fell to Nazi Germany, he spent the wartime period working with United States Army Counterintelligence. At the end of World War II, he emigrated to the United States. After a brief career in business, he entered City College in New York, graduated in 1954, and promptly began graduate study at Princeton University where he earned his Ph.D. in history and Near Eastern studies in 1959.

Except for an early instructorship at Princeton, Sugar spent his entire career at the University of Washington, where he taught for thirty years before his retirement in 1989 and was loved and admired by colleagues and generations of students. He played a major role both in the Department of History and in the Russian and East European Studies Program of the Jackson School of International Studies, which he chaired for six years. He was also instrumental in founding and developing the Department of Near Eastern Studies. Sugar served on the boards or advisory committees of the major national and international organizations in the field of Slavic and east European studies. He chaired the Joint Committee on Eastern Europe and the Association for the Study of Southeastern Europe. He was also the first chairman of the Advisory Council of the East European Program of the Woodrow Wilson Center. He served the American Association for the Advancement of Slavic Studies (AAASS) in many ways, especially through his lengthy partnership with the late Donald Treadgold in editing the Slavic Review. His many contributions to the organizations and scholarship of his field of study were acknowledged with the Award for Distinguished Contributions to Slavic Studies presented by the AAASS in 1994.

Despite these many commitments, and a distinguished and prolific publication record, he was deeply devoted to teaching both undergraduate and graduate students. His formidable erudition, fascinating life, and colorful personality made him a popular and much respected lecturer and earned him the Instructor of the Year award in 1987. He trained many of the scholars currently active in his field in the academy, in government, and elsewhere. At his passing his family and department received an impressive flow of letters from former students with tributes to his enduring impact on their lives.

Sugar's scholarship was especially notable for its geographic breadth and its imaginative presentation of large issues, such as nationalism, ethnic and religious conflict, and political institutions. He edited or authored seventeen books, sixty scholarly articles, and scores of reviews and review articles. His best-known books include Industrialization of Bosnia-Hercegovina, 1878-1918 (1963) and the classic Southeastern Europe under Ottoman Rule, 1345-1804 (1977). He edited A History of Hungary (1990), Nationalism in Eastern Europe (1969), Eastern European Nationalism in the Twentieth Century (1995), and, with Donald Treadgold, the multivolume History of East Central Europe (1974).

The breadth of his scholarship was facilitated by his broad language competence: he spoke six languages and had a reading knowledge of an additional six. His knowledge of Turkish, of Ottoman history, and of the history of all the states of eastern Europe was combined with a deep understanding of issues of ethnicity, nationalism, religion, and political institutions and ideology. His most recent book, East European Nationalism, Politics and Religion (1999) brings together a remarkable body of essays on these subjects published over a period of twenty-seven years. The importance of his scholarship was widely recognized abroad, as evidenced by the award of the 1300 Year Medal he received in 1984 from the Bulgarian government for his contributions to Bulgarian history and by the translation of his books into many languages. 
In the decade following his retirement, he remained a productive writer, a lively presence at the University of Washington, and a regular participant at meetings of the AAASS. It can be said of him that he was a leading figure in the development of eastern European studies in America and in the life of his university.

Herbert J. Ellison

University of Washington

February 2000 